\title{
Credit/Debt and Human Capital: Financialized Neoliberalism and the Production of Subjectivity
}

Abstract: Adding to contemporary debates about the relationship between financialization and neoliberalism, this article investigates their entanglement at the level of subjectivity. Primarily, the article argues that financialization and neoliberalism converge to produce a new form of subjectivity, post-profit homo ceconomicus, an always indebted but credit-seeking enterprise. The value of this approach, I demonstrate, is that it provides theoretical tools capable of grasping the differential production of subjectivity across the uneven and unequal striations of contemporary neoliberal society, from precarious workers of the gig economy to financial sector elites. The article examines two figures that have become central to public and academic debates about neoliberalism and financialization, the lowwaged, precarious worker and the indebted student, to consider how neoliberal subjectivity is produced and distributed unevenly. It concludes that within these fragmentary socioeconomic positions are different instantiations of always indebted but credit seeking human capital.

Keywords: Financialization; Neoliberalism; Subjectivity; Credit; Debt

In the decade since the 2008 financial crash, the social conjuncture formed between neoliberalism and financial capital has shown few signs of unravelling. The further precarization of labour through the venture capital fuelled "gig economy" (Webster 2016) combines with cuts to public spending and ever-growing levels of individual debt. Recent events in Greece have also shown that the technocratic demands of neoliberal orthodoxies and financial markets can neutralise democratic processes and claims of national sovereignty (Stavrakakis, 2013). Even as a wave of reactionary right-wing populism has grown powerful across Europe, financial capital continues to exert influence through perceived concerns with credit-ratings, currency 
devaluations and capital flight. Undoubtedly, this constellation of issues animates a set of urgent political debates.

In post-crash scholarship, there has been a concerted effort to respond to this situation. Across several disciplines, scholars have explored the interrelations between financialization and neoliberalism and the ways they figure the social world (Brown, 2015; Duménil \& Lévy, 2011; Kotz, 2010). Nevertheless, as Aeron Davis and Catherine Walsh (2017) have noted, even though there is a growing consensus that neoliberalism and financialization need to be treated as interrelated concepts the precise nature of their entanglement(s) is hardly a settled matter in scholarly debates. This is particularly true of contemporary social and cultural theory that focuses on questions of subjectivity. Although scholars have often focused on how either neoliberalism (Dardot \& Laval 2013; Leyva, 2018) or financialization (Langley, 2007; Martin, 2002; Mulcahy, 2017) shape subjectivity and experiences of the everyday, a growing body of research is now starting to recognise how subjects are profoundly shaped by the entanglement of financialization and neoliberalism. While much of this scholarship is indebted to Foucault's conceptualisation of the neoliberal subject as an instantiation of homo æeconomicus who conducts herself as an 'entrepreneur of the self,' (2008: 226), theorists have tended to conceptualise finance very differently, normally as either debt and indebtedness (Lazzarato, 2012; Pitcher, 2016) or as investment and credit (Brown, 2015; Feher, 2009; van Doorn, 2014). This has meant that ideas about how finance capital has shaped neoliberal subjectivity have tended to be organised around diverse, even oppositional, ideas.

Contributing to this constellation of politically urgent debates, this article argues that financialization has converged with neoliberalism such that Foucault's reading of the neoliberal subject as a profit-seeking enterprise is no longer legible. Rather, financialised neoliberalism produces of a new form of subjectivity, 'postprofit homo œconomicus', which emerges neither in the figuring of finance as debt 
or as credit but is constructed somewhere between them, as an always indebted but credit-seeking enterprise. As such, this article intervenes in existing debates by offering a more holistic theory of neoliberal subjectivity that elucidates the entanglement of terms that are often situated in opposition to one another.

To develop this argument, the article draws from critically important contributions made by Maurizio Lazzarato $(2009 ; 2012 ; 2015)$ and Michel Feher (2009) to theoretically investigate the ways in which financialization has transformed neoliberal subjectivity. Whilst each of these authors present influential if oppositional ideas about the subject of financialized neoliberalism, this article suggests that the differences between the "indebted man" theorised by Lazzarato and the concept of a value-appreciating subject outlined by Feher, can be overcome by thinking them through a new figure, post-profit homo ecconomicus, who, I argue, is produced ambiguously through interdependent and mutually sustaining logics of finance as credit and debt. I argue that credit and debt - or credit/debt - constitute intertwined and dual forms of financialized biopower, which both offers individualised opportunities for value appreciation whilst delimiting them within the control logic of debt obligations.

As the article demonstrates, the real value of this approach is that it connects theories of homo reconomicus to questions regarding the distributive management of the population through the economy which are implied by the term 'biopolitics'. The model of the subject set out here, therefore, creates new opportunities to conceptualise the uneven and unequal production of subjectivity across neoliberal society. Using this framework, I argue that credit and debt are distributed unevenly across the fragmentary social striations of the economy. To show what is at stake, here, the article examines two figures, the precarious worker and the indebted student, that, as I will explain later, are at the heart of many public and scholarly debates regarding financialization and neoliberalism in the Anglo-American and 
European context. In exploring these avatars of financialized neoliberalism, the article contrasts two of the multiplicity of indebted but credit-seeking subjects that emerge across different socioeconomic positions. It shows that each of these figures is constituted in different constellations of credit/debt that afford different opportunities for value appreciation which are balanced against the potentially existential risks of debt. Consequently, the article contributes to an urgent set of political and scholarly debates by thinking through the ways in which financialized neoliberalism produces and distributes homo æeconomicus unevenly across the socioeconomic locations of the post-crash economy, from the precarious workers of the gig economy to its financial elites.

\section{Neoliberal Homo Econimicus: Foucault and Beyond}

Since their English publication in 2008, Foucault's Birth of Biopolitics lectures have been remarkably influential for researchers exploring both neoliberalism and neoliberal subjectivity. The lectures trace the intellectual project of neoliberalism through a range of thinkers, from the ordoliberals of the Frieberg School to the 'American neo-liberalism' of the Chicago School. Through this genealogical study, Foucault shows that neoliberal governmentality is a project concerned with rearticulating classical liberalism of the $18^{\text {th }}$ and $19^{\text {th }}$ century around a specific set of principles. Firstly, as Foucault (2008: 131-133) shows, neoliberalism rejects the classical conception of the market as a 'natural' sphere of exchange, and instead formulates it as a constructed arena of competition, which the state must play a role in regulating. Secondly, neoliberalism seeks to extend the market through all social relations, such that the entirety of 'the social' becomes 'subject to the dynamic of competition,' (2008: 147).

Through this project neoliberalism develops a distinct concept of human subjectivity, a homo æeconomicus or 'economic man' that is qualitatively different 
from its classical forebearer. As Foucault (2008: 226) argues, 'the stake in all neoliberal analyses is the replacement every time of homo xeconomicus as a partner of exchange with a homo æeconomicus as entrepreneur for himself.' In other words, neoliberalism moves beyond the classical liberal conception of a rational actor making self-interested market exchanges by figuring the subject as an enterprise engaged in competition with others to realise various kinds of profit (monetary, psychic). Indeed, while the term 'homo æeconomicus' largely emerges in Foucault's lectures on American neoliberalism, it is certainly present - implicitly at least - in the ordoliberal concept of Gesellscahftspolitik, that is, its policy of society, which was central to Germany's post-war reconstruction led by economists such as Walter Eucken (2008: 146). As Foucault shows, this policy of society is an attempt to embed the enterprise form within the social body, such that the subject becomes 'a sort of permanent and multiple enterprise,' engaged in competition (2008: 241). In this sense, the figure of a homo æeconomicus as enterprise is legible, even if implicitly, in the ordoliberals' projection of economics into social policy.

It is also worth noting that this entrepreneurial figure is also legible in the influential work of Ludwig von Mises and Friedrich von Hayek even if, as Nicholas Gane (2014: 5) notes, they rejected the term homo æeconomicus. As Dardot and Laval (2013: 106-117) note, the key contribution of these 'Austro-American neoliberals' was to show that entrepreneurship was a 'faculty' that exists in all economic subjects - and not simply some privileged agents - acting within competitive markets. For them, entrepreneurship denoted the set of conducts by which all economic subjects navigate the uncertainty of competitive markets, either to discover relevant information (Hayek) or identify 'good opportunities' from which one can profit (Mises). Consequently, while they didn't embrace the term, their concept of entrepreneurship provided the groundwork for 'a redefinition of homo ecconomicus on broader bases,' by introducing the concept of entrepreneurial creativity as the 
quality through which subjects navigate competitive markets (Dardot and Laval, 2013: 108).

The clearest articulation of neoliberal homo œeconomicus, however, appears in the theories of 'human capital' developed by American neoliberals such as Gary Becker and Theodore Shultz, which radically embeds the enterprise in the social by making the whole life of the subject intelligible as capital. As Foucault (2008: 224229) points out, human capital articulates all domains of human action as capitals, that is, as a series of possible investments in oneself (such as education, training, health) through which one can realise an income, be that monetary or psychic. When figured as a portfolio of human capitals, the subject becomes an enterprise who makes investments in herself to compete within the market and realise profits. As such, human capital crystallises the neoliberal strategy both of shaping individuals into the form of an enterprise and, in doing so, radically expanding economic rationality across all areas of social existence.

Foucault's work on neoliberalism has proven to be extremely prescient. This is no mean feat given that his biopolitics lectures, delivered in 1979, took place just as the neoliberal revolution was about to unfold. Over the last 40 years, 'human capital' has become a central 'strategy' of neoliberal governing (Adamson, 2009a). This is attested to by the way it pervades social policy, especially in the realms of international development (Hunter and Brown, 2000) and education (Gillies, 2011). It can be little surprise, therefore, that the concept of human capital remains central to several contemporary accounts of neoliberalism and neoliberal subjectivity (Brown 2015; Dardot \& Laval, 2013; Feher, 2009; Lazzarato, 2012).

What Foucault did not anticipate, however, was the financialization of the global economy, a process which has taken place alongside neoliberalism. Although definitions of financialization differ across several perspectives, ${ }^{1}$ it can be broadly understood as the increasing power and presence of financial capital in economic, 
social, and cultural practices, which political economists such as Christian Marazzi (2011) have slowly taken shape since the 1970s through a series of financial deregulations, innovations, and shifts in corporate governance. Over the last 20 years, the work of sociologists bears witness to the degree to which financialization has colonised the social by showing how it has transformed both everyday life (Martin, 2002) and subjectivity (Langley 2007; Mulcahy, 2017).

But there is now a growing consensus that neoliberalism and financialization need to be treated as fully entangled concepts. Researchers (Duménil \& Lévy, 2011; Helleiner, 2010; Kotz, 2010; Lazzarato 2012) have now established that the rise of finance capital and neoliberalism are intertwined in the economic transformations of the ' $70 \mathrm{~s}$ and ' $80 \mathrm{~s}$ and are implicated in each other as conditions of their own possibility, even if, amongst these authors, the relations of causality are disputed. Most recently, Wendy Brown (2015: 70-71) has unequivocally argued that financial capital has entirely transformed neoliberalism and 'its formulation of markets, subjects and rational action.' Given that the conjuncture of financialization and neoliberalism still defines the present, a pressing question in contemporary debates is how financialization has transformed neoliberal governmentality. Even more crucial: what are the consequences of the interconnections between financialization and neoliberalism for the enterprise-subject?

My own argument is that the entwining of financialization and neoliberalism has rapidly transformed neoliberal subjectivity, rendering the concept of a profitseeking enterprise untenable as the legible figure of neoliberal governmentality. Instead, financialized neoliberalism corresponds to a new figure, post-profit homo ceconomicus, who is uneasily produced in the tension between finance-as-debt imbued with a logic of control and finance-as-credit with opportunities for speculation and value appreciation. Importantly, in invoking the concept of a postprofit homo æeconomicus I am not making a broader claim about the end of 
contemporary capitalism's regime(s) of accumulation. As I will show, regimes of profit accumulation have certainly been transformed by, but ultimately remain central to, financialized neoliberalism. Rather, I argue that the interactions between financialization and neoliberalism have rendered the construct of a profit-seeking enterprise obsolete as the grid of intelligibility for the conducts correlated to neoliberal subjectivity. My central assertion is simply that a different subject, not organised around the logic of profit but around the dual, complex logics of finance as both credit and debt has now become legible.

To make this claim, I now draw upon and further develop approaches from Feher (2009) and Lazzarato (2012; 2015) whose work has engaged with questions of neoliberal subjectivity in the era of financialization, and has been influential for scholars exploring a range of issues surrounding financialized neoliberalism (Adkins, 2017; Brown, 2015; Pitcher, 2016; van Doorn, 2014). I argue that while Lazzarato's concept of 'indebted man' accurately captures the debt's function as a control technique, a speculative logic has now intervened in the conduct of the subject which his work cannot properly account for. I then introduce Feher's concept of credit-seeking human capital as one way of thinking about this speculative orientation. From there, I argue, it is possible to fully develop the concept of postprofit homo æeconomicus I am proposing, combining their perspectives to complicate contemporary understandings of financialized, neoliberal subjectivity.

\section{Indebted Subjects or Credit-Seeking Human Capital?}

As scholars have noted, the imbrication of neoliberal policy and finance capital has integrated everyday life into a 'financialized' regime of accumulation. The precarisation of work and correlated suppression of wages achieved through, for example, neoliberal policies aimed at weakening unions, ${ }^{2}$ has delivered new profits through credit markets that fuel housing, education and consumption as a corrective 
to stagnant household incomes (Marazzi, 2011: 28-35). As Costas Lapavitsas (2009) notes, this has led to systematic 'financial expropriation' as a considerable proportion of waged incomes now accrue to banks and financial institutions through debt servicing. Moreover, consumer debt is also folded into more exotic speculations since it now tends to be securitized, that is, sliced up and re-bundled into derivative financial products that enable new rounds of accumulation on financial markets (Bryan, et al., 2009).

Consequently, contemporary society is dominated by debt and the experience of indebtedness. As Lisa Adkins (2017: 450-451) argues, debt is now entangled in wages, health care, education, and housing, such that 'debt is not only necessary to meet the demands of everyday life, but debt and indebtedness have become defining features of contemporary existence.' A key feature of this transformation, for Adkins, is that 'indebted labouring has now become a permanent feature of work and working.' The implications of this point have considerable bearing on the analysis I seek to develop here. If debt now permeates both life and labour, then this begs the question of how it has transformed the figure of neoliberal homo æeconomicus. In what ways might a profit-seeking enterprise co-exist with debt?

Lazzarato's work on 'indebted man' $(2009 ; 2012 ; 2015)$ provides an excellent starting point for thinking through this problem. Lazzarato's central thesis is that debt has become neoliberalism's primary governmental mechanism, arranging and governing the social by instituting a hierarchical power relation between creditors and debtors that reaches both across and through society. For Lazzarato, this power relation is constitutive of the social, transforming class relations so that they 'no longer depend on the opposition between capitalists and wage earners,' but, rather, are organised through the relation 'between debtors and creditors,' (2015: 66). But debt is also more than a purely economic relation; it also 'functions as a 
mechanism for the production and government of collective and individual subjectivities,' (Lazzarato, 2012: 29). In other words, debt is a control technique that both draws individuals - as debtors - into an uneven, asymmetrical power relation with creditors and implies a form of subjectivation with its own specific conducts.

But how does debt function as a technique of control? Drawing on Nietzsche, Lazzarato (2012: 40) shows that debt engenders a morality that implies its own form of subjectivation. For debtors are subjects who, drawn into a relation of obligation with their creditor, are made 'capable of promising.' Debt thus inscribes concepts of 'guilt', 'duty', and 'responsibility' into the subject, binding them to a creditor and the future to the present. Through the obligation of promising, debt institutes an injunction to conduct oneself both now and in the future in ways that are 'trust-worthy', predictable and make the subject capable of repaying her debt.

In contemporary capitalism, Lazzarato (2009: 132) argues, this logic of debt ensures "control over a "labour force", by securing its subjection as "human capital" within the frame of "enterprise society".' Debt produces a subject who must conduct herself as a neoliberal homo æeconomicus in order to meet her obligations to creditors. Nonetheless, Lazzarato's enterprise-subject is not the utopian figure theorised by neoliberal intellectuals, which promised to transform workers into selfrealising owners of various kinds of capital. The dream of an enterprise society is now situated in a context that does not fulfil its promise; 'self-realization, freedom and autonomy collide with a reality that systematically nullifies them,' (Lazzarato, 2015b: 186-187). In the debt economy, human capital becomes 'indebted man', an entrepreneur of the self with little prospect of realising any rewards. Always in debt and always precarious, the enterprise-subject is 'restricted to managing, according to the terms of business and competition, its employability, its debts, the drop in wages and income, and the reduction of public services,' (Lazzarato, 2012: 94). 
While Lazzarato's work usefully demonstrates how debt is intertwined with the production of homo æeconomicus, several theorists have complicated his account of indebted life whilst also gesturing to developments that it cannot account for (Adkins 2017; Pitcher, 2016; Stavrakakis, 2013). In particular, Adkins' (2017) writes against Lazzarato's claim that indebtedness empties time by giving both the present and the future over to creditors. Adkins insists that the temporality of debt 'has a complexity that is not entirely captured,' (452) by his account. Disrupting the gendered subject of Lazzarato's indebted man, Adkins argues that financialization strategies targeted mainly at women introduce a 'calendrics of debt' that does not empty time but imposes a specific rhythm that 'regulates and organizes [the subject] and claims them as its own,' (453).

The novelty of Adkins' approach is to show how Lazzarato's temporality of debt has been transformed by securitization. For Adkins, securitization means that profit is no longer simply accumulated through 'interest accrued across pre-set blocks of time, but [...] from trading on debt itself and especially the contracted income streams that debt necessarily entails,' (2017: 456). On the one hand, the emphasis on contracted income streams, Adkins argues, has reshaped the temporality of debt, from one of linear time leading to final repayment to one simply geared around continuous debt payments so that the process of debt servicing becomes everpresent. On the other hand, the bundling of consumer debt into the speculative experiments of financial markets has also greatly disrupted the calendrical rhythm of debt. The subject is now situated in a speculative time of 'payment and the possible' in which payments maybe be sped up, slowed down, or suspended, 'for those are the schedules that are continuous with those of the indeterminate speculative time of securitized debt,' (2017: 458).

There are two key implications to be drawn from Adkins' analysis. Firstly, the speculative time that Adkins outlines is not one in which the subject escapes 
from her creditor but one where the creditor-debtor relation becomes permanent, even if non-linear, unmooring the control logic of debt from the finality of repayment and making it omnipresent through the supple and dynamic temporalities of payment. In this respect, Adkins sketches a specific instantiation of what Lazzarato $(2012 ; 2015)$ understands as contemporary capitalism's drive to make debt infinite so that its regime of control never reaches finality. After all, 'the creditordebtor relation can never be settled because it assures both political domination and economic exploitation,' (Lazzarato, 2015: 88).

Secondly, while Adkins' work is not explicitly concerned with neoliberal subjectivity, her analysis does point to the ways that a new logic of homo oconomicus is taking shape, one that cannot be reduced to the profit-seeking enterprise which Lazzarato insists has failed. Adkins (2017: 456) argues that the time of securitized debt is one that produces a speculative subject, one for whom the temporality of payment orients human conduct around speculation on possible futures. This can be seen in Adkins' account of mortgage lending calculus and its repayment schedules, which are no longer based on predicted and probable wage rates extrapolated from present earnings. Instead, once debt is securitized, creditors organise borrowing around 'the possibilities and potentials [of] debt, and especially their possibilities in regard to debt servicing.' Borrowing is 'indexed to possible futures,' rather than current income. In other words, debtors now borrow resources from an imagined future, meaning that 'the present is remediated by futures which have not - and may never - arrive.'

Adkins' work gestures towards the ways that a speculative logic has now interceded in the government and conduct of subjects, one which cannot easily be accounted for by the figure of the profit-seeking enterprise that Lazzarato still sees as legible in contemporary capitalism. Rather than heralding these developments as an end to neoliberal homo ceconomicus altogether, I want to argue that they are 
suggestive of a new rationality of neoliberal subjectivity which becomes legible in financialized neoliberalism and has little to do with the cost-benefit rationalities that have hitherto defined the subject's conduct. To develop this argument, I now turn to the work of Michel Feher, whose own critical reworking of human capital can help to elaborate on this shift in the rationality and conduct of the neoliberal subject.

Feher's work on neoliberalism (2009) is fundamentally concerned with rethinking neoliberal homo oconomicus in light of its entanglement with financial logics, practices and techniques. Crucially, Feher does not understand financialization through the lens of indebtedness making his analysis very different from Lazzarato's, which seemingly holds onto the same (if ultimately doomed) profit-seeking enterprise delineated by Foucault. Rather, Feher is much more interested in the speculative, 'productive' character of credit and the ways that is has intervened in neoliberal subjectivity by transforming the logic of the enterprise and with it the very entrepreneurial rationalities that are supposed to animate homo œconomicus. Feher's key point, then, is that the intervention of these financial logics has signalled the end of the profit-seeking subject theorised by neoliberal thinkers and the emergence of a different instantiation of neoliberal subjectivity which he calls the 'neoliberal condition'.

Picking up on a shift largely marginalised by theorists such as Lazzarato, Feher (2009: 27) argues that this neoliberal condition hinges on the revolution in corporate governance precipitated by the 'ideology of shareholder value'. As scholars of financialization have long understood (Aglietta \& Rebérioux, 2005; Lazonick \& O'Sullivan, 2000), the discourse of shareholder value emerged out of the financial deregulations of the 1980s and has replaced the older strategy of retaining and reinvesting corporate profits with the injunction to increase shareholder value at all costs. This has reoriented corporate strategies towards increasing their stock's value through practices like distributing high dividends, which signals to investors 
that the stock is credible and worthy of their confidence, or share 'repurchasing' where corporations buy a volume of their own stocks to increase their value.

For Feher (2009: 27), this shift is important because it turns the strategy of the enterprise away from the realisation of long-term profits and towards 'maximizing the distribution of dividends in the short run $[\ldots]$ its major preoccupation is capital growth or appreciation rather than income, stock value rather than commercial profit.' Feher argues this shift is correlated to a transformation of human capital not anticipated by neoliberal thinkers. Human capital is therefore "less concerned with maximising the returns on his or her investments $[\ldots]$ than with appreciating, that is, increasing the stock value of, the capital to which he or she is identified,' (2009: 27). In Feher's work the neoliberal condition is thus differentiated from its liberal predecessor not by the extension of profit-seeking logics across all spheres of existence, but by the exhaustive proliferation of a financialized version of human capital concerned with credit, credit-worthiness, and the objective of 'self-appreciation'. As Brown (2015: 33), clarifying Feher's claim, has put it 'the project is to self-invest in ways that enhance its value or to attract investors through constant attention to its actual or figurative credit rating, and to do so across every sphere of its existence.'

The crucial point, however, is that Feher's analysis announces a radical departure from the possessive individualism that neoliberal thinkers such as Becker and Schultz thought would proliferate through the expansion and calibration of the market ("everyone an owner!"). As Feher (2009: 28) insists, 'the relationship of a neoliberal subject to his or her human capital cannot be defined as ownership and escapes the liberal realm of possessive individualism [...] neoliberal subjects do not own their human capital; they invest in it.' Human capital is not a property than can be sold, but a series of investments in skills and conducts that can be 'diversified' and 'modified' to enhance its value. In a move that fleshes out the implications of 
Adkins' point within the context of neoliberal homo æeconomicus, Feher thus argues that the relation between the subject and its human capital is not 'possessive' but 'speculative'. That is, financialized neoliberalism has transformed human capital into a speculative project where possible futures have become intertwined with strategy of value appreciation.

This project is deployed through a governmental regime, which governs subjects 'by inciting them to adopt conducts deemed valorizing and to follow models for self-valuation that modify their priorities and inflect their strategic choices,' (Feher, 2008: 28). The question is thus one of identifying the practices through which this subject is produced. As Feher notes, neoliberal discourses around the "employability", "bankability" or "marketability" of 'a person's skill, talent, or invention are all meant to be partial estimates of the value of human capital.' As such, these discourses represent ciphers for a set of policies and practices through which individuals can both measure and appreciate their value. To this list one might also add the recent proliferation of free credit-rating apps (such as those now offered by Experian, Noddle, and so on) as tools through which individuals can monitor their value through the proxy of their credit score. This set of governmental practices permeates the entirety of the subject's life so that 'the pursuit of education, training, leisure, reproduction, consumption, and more are increasingly configured as strategic decisions and practices related to enhancing the self's future value,' (Brown 2015: 33-34).

\section{Credit/Debt and Financialized Human Capital}

In the analysis I have developed so far, neoliberal homo xeconomicus remains fragmented across two seemingly oppositional understandings of finance that emerge in the contrast between Feher and Lazzarato, but also tend to persist in contemporary scholarship. ${ }^{3}$ On the one hand, finance is figured primarily as debt, a technique of 
domination and control, and, on the other one hand, finance operates as credit, a mechanism for speculations on human capital appreciation. This opposition reflects Miranda Joseph's observation (2015: 20-21) that while finance as 'debt' has negative connotations, as 'credit' it gains a positive, socially productive valence. But as Joseph argues, the modalities of credit and debt are both ambiguous and intertwined. While they coincide inasmuch as credit received is also debt owed they are also 'separated across social space and time [...] between loan and repayment,' (author's emphasis). Two sides of the same coin, perhaps, but also crucially different, Joseph's analysis indicates that credit and debt need to be understood both together and in their difference. These observations prompt the question not only of how the ambiguous duality of credit and debt governs homo œeconomicus, but also how this duality might bring together the seemingly oppositional fragments of neoliberal subjectivity outlined above.

My own intervention seeks to theorise credit and debt as intertwined but separate and co-existing operations that are co-constitutive of a financialized, neoliberal homo æeconomicus. The final sections of this article are thus designed to complicate and move beyond the opposition between finance-as-credit and financeas-debt I have outlined above through a synthesis of Lazzarato and Feher's theoretical contributions. As I will show, at stake in this analysis is not only a theory of neoliberal subjectivity that encompasses and elaborates its relationship to the intertwined modalities of credit and debt. Rather, the theoretical contribution I develop also provides tools with which to concretely theorise the social stratification of human capital, and, in doing so, demonstrates the ongoing value of investigating the intertwining of neoliberalism and financialization at the level of the everyday. To pursue this trajectory, the first task is to identify points of convergence through which indebted subjectivity can be brought into relation with concept of value appreciating human capital. A crucial point to consider is Feher and 
Lazzarato's shared conviction that the process of financialization signals the end of homo æeconomicus as a profit-making enterprise. But even here considerable differences need to be overcome. For Lazzarato (2012: 113), the end of the profitseeking enterprise signals the failure of the neoliberal project. Debt thus acts as a disciplinary apparatus designed to illicit economic behaviours but forecloses the possibility of its rewards in the form of profit. Conversely, Feher (2009) argues that the end of the profit-seeking entrepreneurial self is at the heart of the shift to the neoliberal condition. Neoliberal subjectivity, in this sense, has not failed but in fact only emerged in the shift from a logic of profit to one of value appreciation. How might one reconcile these seemingly oppositional standpoints on the fate of 'postprofit' homo æeconomicus?

The approach taken here is to consider both perspectives as partial representations of the same financialized, neoliberal governmentality. One hypothesis that merits further consideration is that Lazzarato's insistence that the project of neoliberal homo æeconomicus has failed is, in part, based on a misrecognition of the centrality of the concept of shareholder value in financial capitalism. For Lazzarato (2012: 100-101) shareholder governance is the mechanism by which finance has been able to take control of both corporations and public institutions, and 'prescribe forms of valorization, the accounting procedures, the salary levels, the organization of labour.' Shareholder governance appears as a disciplinary technique, instituting debt relations through the provision of low wages and social security payments which can only be resolved by the subject with recourse to finance. Lazzarato thus subordinates shareholder governance to the logic of debt, rather than seeing it as a template for financialized homo æeconomicus. One possibility, then, is that Lazzarato's framework misses the shift from profit to appreciation, just as Feher, writing shortly after crisis, does not necessarily foresee the deleterious effects of debt. 
If post-profit neoliberal subjectivity does not represent the failure of human capital but its transformation, then a question arises as to whether the neoliberal subject can simultaneously be an indebted subject formed through the veiled hierarchy of debt with its attendant concepts of 'responsibility' and 'guilt' and a 'self-appreciating' portfolio of capitals who is compelled to self-invest in order to appreciate their value. On this front, it is worth remembering that Lazzarato argues that the subjectivating power of debt has no content regarding the work on the self that it imposes. When constituted as debt, finance does not 'mobilize physical or intellectual capabilities [...] but the morality of the debtor, his mode of existence (his “ethos”),' (Lazzarato, 2012: 55). The morality of debt thus performs an ethical subjectivation which, whilst demanding certain conducts to meet the responsibilities of debt, leaves the content of those conducts uncertain. Within the limits of this uncertainty, limits which are themselves demarcated by the neoliberal contours of contemporary society, space thus emerges to accommodate a form of selfappreciating human capital as the grid of thought, actions, and conducts which is 'secured' by the ethico-subjectivation of debt, as Lazzarato (2009: 132) might put it, within the bounds of an 'enterprise society'.

Post-profit homo æeconomicus would then be configured in a conjuncture where debt substantively functions to constrain the subject to 'work on the self' through the constant task of investing and attracting investors to appreciate their value. From this perspective, the neoliberal subject appears as an indebted but always credit-seeking manager of their portfolio of human capital. But this already implies a more complicated relationship between subjects and their debt than is perhaps granted by Lazzarato. If, as Feher (2009: 34) argues, dividends are realised through the neoliberal subject's speculations on their human capitals, then speculating on dividends for the purposes of what in corporate parlance is referred to as debt servicing also becomes a means of value appreciation insofar as good debt 
management can maintain and improve one's credit-rating. Debt, as ethicosubjectivation, thus ambivalently enters the circuits of self-appreciation, both maintaining its control of the subject (in the end, consistent debt servicing undoubtedly represents an ethical conduct engendered by the responsibilising effect of indebtedness) and becoming a tool for the value appreciation of the self.

What is at stake, then, is precisely the doubling of the relation between finance and the neoliberal subject, which operates through and between the polarities of credit and debt at the same time, that is, as credit/debt. Finance figures the subject in a potentially complex array of intersections between finance as both the control logic of debt, and the value-appreciating opportunities of credit. If finance emerges as both credit and debt, then while one can agree with Lazzarato (2012: 24) that 'debt is finance from the perspective of the debtors who have to repay it,' it is important to consider that finance is also credit from the perspective of investees who can make use of it. As credit/debt, finance thus operates ambivalently between both poles, proliferating debt as a technique of control alongside and in an intersection with the self-realising potential of credit. This poses the question of how to conceptualise this matrix of financial power and the ways in which it produces neoliberal subjectivity.

An important consideration is the biopolitical aspects of credit/debt. For Foucault (1998: 136-138), of course, biopower referred to a new kind of power that emerged in the $18^{\text {th }}$ century and outmoded sovereign power, which was exercised discontinuously 'through the death [the sovereign] was capable of requiring.' In contrast, biopower denotes a continuous and diffuse power designed to 'foster life or to disallow it to the point of death.' Crucially, biopower was co-emergent with capitalism which, as Lazzarato (2009: 116) points out, required new techniques to manage an emerging field of social life and conduct. The emergence of biopolitics was thus part and parcel of capitalism's 'distributive management' of the social, 
fostering 'segregation and social hierarchisation,' and joining 'the growth of human groups to the expansion of productive forces and the differential allocation of profit,' (Foucault, 1998: 141). Biopower is thus present at all levels of the social body, regulating and distributing the (unequal) possibilities of life to serve broader objectives such as productivity and accumulation.

In the regime of financialized neoliberalism, as Fiona Nicoll (2013: 389) has argued, biopower is rearticulated through finance, which, operating under the imperatives economic growth, sustains and fosters "life" through financial discourses and practices. For Nicoll, the financialized articulation of biopower thus remains coextensive with the socioeconomic striations of late capitalism and is distributed unevenly across the biopolitical spectrum from 'social death' and 'financial incapacitation' to 'financial wealth'. Borrowing these insights, the argument forwarded here is that credit and debt operate as two fundamentally intertwined modalities of financialized biopower, which both simultaneously and differentially produce and govern homo ceconomicus. A central concern is therefore with how homo oeconomicus is produced differentially through credit and debt and its 'distributive management' of the uneven social relations that are constituted in the economy.

As I will now demonstrate, taking this approach affords a substantial opportunity to move beyond the tendency for social and critical theories of homo œeconomicus to homogenise subjectivity, regardless of its socioeconomic position, under the figure of the 'enterprise-subject' or 'self-appreciating capital'. While such a move may help us to understand, for example, neoliberal subjectivity as a strategy designed to efface class relations and the exploitation inherent within them by making everyone an enterprise (Read, 2009: 31-32), it also risks flattening all lived experience into the intelligible matrix of profit-seeking or value appreciating conducts. Conversely, the approach developed here is designed to disrupt this 
homogenising tendency by showing how the neoliberal subject is, in fact, differently and unevenly produced through credit/debt across the striations of the economy.

\section{Figures of Homo Economicus: Precarious Workers and Indebted Students}

One way to think through the problem of socioeconomic distribution and neoliberal subjectivity is to revisit Lazzarato's claims about the class relations constructed through the hierarchy of the creditor-debtor relation. For Lazzarato (2012: 35) this hierarchy 'shapes all social relations in neoliberal economies,' and relates to a kind of class politics that transforms most of us into debtors to consolidate financial elites as a creditor class. But for Lazzarato (2015b: 12-13) the indebted class is also 'dispersed, fragmented and precarious.' The condition of 'indebted man' is produced across 'a multiplicity of situations of employment, non-employment, occasional employment, and greater or lesser employment.' It encompasses portions of the middle class, impoverished by wage deflation but who maintain consumption levels through credit (2012: 110-111). And it also includes students, whose loans make them a model of indebted man (2015b: 70). Moving beyond Lazzarato, I argue that this fragmented class cannot be homogenised under the figure of 'indebted man' but is unevenly produced by the modulations of credit/debt as a multiplicity of different indebted but credit-seeking subjectivities.

Within these fragmented but multiple sites of subjectivity, the cases of precarious workers and indebted students speak to some of the pressing social problems created by financialized neoliberalism in the European and AngloAmerican context. On the one hand, the increase in precarious work and workers in contemporary 'western' societies has long been understood as symptomatic of neoliberalism's weakening of unions and flexibilization of labour (Deranty, 2008; Lazzarato, 2009; Standing, 2016[2011]). The recent emergence of the 'gig economy' particularly in the US and the UK promises to exacerbate this problem by bringing 
new forms of precarious 'microwork' figured around short contracts lasting only as long as single, non-repeatable tasks (Webster, 2016). On the other hand, while issues around student debt have already been explored in financialization scholarship in the US context (Adamson, 2009b; McClanahan, 2017), UK government's 2010 decision to treble university tuition fees from around $£ 3000$ to $£ 9000$ per year has also rekindled important socio-political debates about the financialization of university this side of the Atlantic. Moreover, beyond their timeliness, as I will now demonstrate, contrasting these cases usefully reveals how the divergent social positions each occupies implies a differential production of subjectivity across the credit/debt distinction.

The case of precarious workers can be best understood by first turning to recent work by Niamh Mulcahy (2017: 228) which analyses the ways in which credit/debt is distributed across different socio-economic locations. Mulcahy notes that these differences are configured by financialization through the categories of "prime" and "subprime" borrowers, which not only differentiate between high-value and low-value subjects but also reproduce them as 'a consequence of the high interest rates applied to [subprime borrowers] in accordance with already precarious conditions like low income or unpredictable employment.' Alongside other factors, this means that experiences of financialization are likely to be profoundly worse for precarious, low-income, or otherwise subprime borrowers; they are 'likely to be oriented around the acquisition of debt and strategies (or lack thereof) for future repayment rather than strategic personal investment,' (Mulcahy, 2017: 224-225).

Precarious, low-waged workers who seek to maintain their existence through, for example, payday loans are thus less likely to experience finance as selfappreciation then they are to be both subjected to, and subjectivated by, it under the full weight of indebtedness. Indeed, as subprime borrowers are increasingly forced into high-interest or otherwise stringent loan conditions, finance, as debt, becomes a 
permanent part of existence. The task of value appreciation, then, as Feher (2009:27) might put it, becomes a constellation of economic conducts aimed at preventing value depreciation by meeting one's debt obligations. On the biopolitical spectrum, precarious workers are thus likely to be bounded within the existential risks of 'social death' and 'financial incapacitation', and debt circulates within this site of subjectivity both as a logic of control and as an inhibitive existential risk constraining the possibilities of value appreciation. The precarious worker's 'biopolitical location' is thus a paradox homologous to Lazzarato's homo ceconomicus in which the neoliberal freedom implied by becoming human capital and thus administering one's own life through market choices is nullified by the poverty trap that awaits them.

The fuller implications of this issue can be understood by turning to empirical work from Shildrick et al. (2012), which investigates poor and precarious lives in the UK. Their research demonstrates that the combination of infrequent and precarious employment conjoins with growing indebtedness through payday loans and other 'subprime' debt to leave individuals trapped in the cycle of poverty. The reluctance to enter debt, precisely because of the fear of these cycles, is reflected in experiences of their participants. As one put it, 'sometimes you get desperate. I mean some weeks if you have to borrow off somebody and the next week you're in an even bigger hole,' (184). Debt presses down as a burden that might help one to 'get by' as the authors put it but does not become a form of strategic self-investment.

But Shildrick et al. (2012: 169) also draw critical attention to the ways in which this problem can be compounded by the social stigmatisation engendered by discourses of the 'undeserving poor' that have become a hallmark of neoliberal societies, and which tend to construct poverty as essentially 'something to be ashamed of, a self-inflicted condition and failure [...] to manage.' Certainly, such discourses represent devaluations that places some outside the realms of social value. 
The implication is that, within this fragmentary site of the economy, becoming postprofit homo oeconomicus means facing stagnating social as well as economic value, or even a vicious cycle of value depreciation, which only serves to perpetuate precarious life.

In this respect, it is particularly interesting that Shildrick et al. found that the category of 'underserving poor' appeared to have little sociological basis but was frequently called upon by impoverished individuals to 'castigate and blame' unknown others. The researchers describe this as a distancing narrative "whereby individuals and families sought to maintain respectability and distance themselves from the shame and stigma of living in poverty,' (Schildrick et al., 2012: 169). Within the framework being developed here, attempts to differentiate the self from problematic narratives of blame and guilt in order to hold onto 'respectability' should be understood as a way of maintaining self-worth. In other words, such narratives provide ways of preserving social value in the face of what would otherwise become a spiral of social and economic depreciation.

This formation of neoliberal subjectivity can be contrasted with university students who access their education through finance, a figure which for Lazzarato (2015: 70) epitomises indebted man. Certainly, financialized students are produced more uneasily between the modalities of credit and debt than would be allowed by Lazzarato. From one perspective, students have opportunities for value appreciation by adding a degree - and associated skills, capacities and attributes - to their portfolio of human capitals. Several researchers have examined how university education is now understood by students as a self-investment, which is commonly measured through the proxy of 'employability' (Moreau \& Leathwood, 2006; Tomlinson, 2008; Tymon, 2013). Nonetheless, while degree certificates represent crude but concrete economic measures of value, the analysis proposed here also calls 
for thinking through the less tangible aspects of human capital and strategies of value appreciation.

On this front, new research by Gordon Clark et al. (2015) is informative. It shows that students believe extra-curricular activities undertaken at university help them develop attributes such as 'confidence' and 'maturity' that enhance their employability, or, to put it another way, appreciate their value. The value of confidence, which here recalls the concept of 'market confidence', should not be underestimated. After all, one of Feher's (2009: 28) points about the neoliberal condition is that there is a relationship between the subjective dimensions of confidence and the economic value of human capital, even if this relationship can't be easily quantified by cruder market measures.

Recent research by Eivis Qeneni et al. (2014) brings the critical importance of this particular issue into sharper focus. It shows that student confidence in their own employability is distributed unequally, and that this has a gendered element: female students were $50 \%$ less confident in their employability than their male counterparts. This is important because if, as the authors argue, these selfperceptions 'help determine what individuals do with the knowledge and skills they have,' (Queneni et al., 2014: 202) then it is not too outlandish to suggest that problems of 'self-valuation' translate into economic valuations in the labour market. ${ }^{4}$

The potential economic benefits of self-appreciating subjectivity for the circuits of finance capital crystallises in the American context. As Morgan Adamson (2009b: 102-103) points out, in the US a large and exotic private market for student finance has resulted in the development of the 'Human Capital Contracts'. Not a traditional student loan, Human Capital Contracts allow financial investors to buy a share of a student's human capital in return for financing their university education. The investor is thus entitled to a percentage of the future income of the human capital under contract. It is not difficult to see how this might be cast in terms of the 
analysis developed here: rather than the steady drip of loan interest these kinds of contracts allow investors to benefit from the potentially lucrative increases in the value of human capital. Although such exotic financial instruments do not exist in the UK context (for now at least), the example serves to illustrate the ways in which processes of value appreciation can be appropriated by others in secondary markets.

This example is thus also a reminder that finance - even when experienced as value appreciating credit - is also debt that draws subjects into relation with creditors and implies moral obligation. Opportunities for value appreciation are thus tempered by the ubiquitous student loan debts that loom large in the life of human capital. Through an empirical, longitudinal study of changing student attitudes towards debt, John Horton (2017: 286) suggests that debt is now seen by students as a part of their everyday lives. Crucially, Horton shows that it is experienced as a 'burden' or responsibility. Indebtedness is felt as a 'as a (massy, troubling, pressing) co-presence, lived-with and worked around' through 'a set of everyday processes of muddling through, keeping going and managing debt.' With this passage, one can begin to see how the mechanisms of student loans produce forms of responsiblisation comparable with Lazzarato's indebted man. The sense of 'keeping going' and 'managing debt' already assumes the kind of subjectivity that is locked up by debt within established neoliberal frameworks. "Good" debt management is nothing if not the set of practices which make the subject predictable and 'capable of honouring his debt,' (Lazzarato 2012: 40).

In this sense, financial flows operate ambiguously through the mechanisms of student finance as both value-appreciating credit and the responsiblizing burden of debt. Such ambiguities emerge within the transcripts of interviews Horton (2017: 284) conducted with students as part of his project. At one level, indebted students embark upon a process of value appreciation with some opportunity to travel upwardly through the biopolitical spectrum towards financial wealth. As one student 
put, it 'I don't like debt but if you look at it as an investment in your future then it's easier to accept.' A palpable discomfort with debt is, at least temporarily, circumvented by the promise of future value. Furthermore, the potential for a virtuous circle to emerge here, one in which debt itself becomes incorporated into the logic of value appreciation, shouldn't be forgotten. After all, taking on debt and successfully managing it is a kind of training or capital in of itself that, as I argued earlier, can become central to strategies of value appreciation by increasing credit scores.

Nevertheless, such opportunities do not signal emancipation so much as they mark the very limits of freedom for post-profit homo æeconomicus. Strategies of value appreciation cannot be extricated from the morality of debt - a student loan is also 'basically selling your soul,' (Horton 2017: 285) as another student commented, an expression that neatly captures the socio-political expectations that surround student finance. In short, the strategy of human capital is one valorised by the established neoliberal framework as responsible conduct. The implicit threat is that attempts to depart from this constellation of conducts signal moral failure and may act as a catalyst for value depreciation with potentially dire consequences for human capital's capacity to take responsibility for and 'administer' its own life.

For both precarious workers and indebted students, then, credit, as appreciation, and debt, as control, become implied within each other as interdependent and mutually sustaining logics that cannot be easily separated in the formation of subjectivity. What substantially differentiates these figures is the dispersal and distribution of finance as credit/debt, which combines differently across the 'prime' and the 'subprime', unevenly producing indebted but selfappreciating human capital in different, fragmented socioeconomic sites of subjectivity. The result is differentiated encounters with finance as various levels of 
a delimited freedom and constraint, appreciation and control, distributed unequally across a debtor class.

\section{Conclusion}

This article has shown how financial and neoliberal logics combine to produce the subject as a post-profit homo æeconomicus: one who is more or less indebted, has more or less opportunities for value-appreciation, but who is always produced as an enterprise, albeit of a particular kind. It thus demonstrates that financialized neoliberal subjectivity is formed through the interwoven logics of credit and debt and does not fit within the neat categories of indebted subjectivity or selfappreciating human capital. Rather, neoliberal subjectivity is modulated in the intersections between credit/debt, that is, within their coincidence and through their differences.

The broader value of this strategy is that it complicates contemporary conceptions of homo oeconomicus, by drawing ideas about neoliberal subjectivity together with questions of social stratification. My own sketch of financialized homo œconomicus crystallises in the differences between two sites of subject formation, the precarious, low-waged worker and the student who funds their education through loans. But these differences also raise broader questions about the relationship between neoliberal subjectivity and issues of class, race, and gender which mark the uneven striations of the economy. In its sociological dimensions, the theoretical insights developed in this analysis point towards further work which addresses these questions in an analysis of the differential forms of neoliberal subjectivity that emerges between the modalities of credit and debt as financial practices, techniques and logics are distributed across the social.

But there are, I hope, also political implications that might be teased out from this analysis. Feher (2009: 41) has argued that the neoliberal condition requires 
new principles of political engagement and resistance. The logic of value appreciation raises the prospect of a political resistance to financialized neoliberalism that challenges, 'from its own perspective, the question of what constitutes an appreciable life.' Feher thus calls for a politics that deploys alternative frameworks of valuation, imagines alternative forms of subjectivity - both collective and individual - and new ways in which they might 'appreciate'. By demonstrating that finance is not simply about value appreciation but about the dual modalities of credit/debt, my own analysis serves as a reminder that the politics Feher calls for must also imagine forms of appreciation and investment that avoid the individualising responsibility of debt; it must create collective practices of value appreciation without guilt. In a world still largely defined by the very social formations that caused the crash it has not yet recovered from, this politics of appreciation without debt sketches out one starting point for thinking social change.

\section{Notes}

1. For an overview of these approaches see work by Costas Lapavitsas (2011) and Shaun French et al. (2011).

2. For an account of neoliberalism's attack on unions and its relationship to objectives like reducing wages, see Dardot \& Laval's The New Way of the World (2013: 173-174).

3. As mentioned earlier, beyond Feher and Lazzarato there is a tendency for accounts of financialised homo economicus to be separated between a figuring of finance either as debt or as credit (For example, see: Brown, 2015; Pitcher, 2016; van Doorn 2014).

4. Although there is little space to investigate these issues here, these findings demonstrate the urgent need to further understand not only the gendered distribution of confidence but also its classed and raced dimensions in future too.

\section{Acknowledgements}

\section{References}

Adamson, M (2009a) The human capital strategy. Ephemera, 9(4), 271-284 
Adamson, M (2009b) The financialization of student life: Five propositions on student debt. Polygraph, 21, 97-110.

Adkins, L (2017). Speculative futures in the time of debt. Sociological Review, 65(3), 448-462.

Aglietta, M and Rebérioux, A (2005) Corporate Governance Adrift. Cheltenham: Edward Elgar.

Brown, W (2015) Undoing the Demos: Neoliberalism's Stealth Revolution. New York: Zone Books.

Bryan, D, Martin, R \& Rafferty, M (2009) Financialization and Marx: Giving Labor and Capital a Financial Makeover. Review of Radical Political Economics, 41(4), 458-472.

Clark, G et al. (2015) "It's everything else you do...": Alumni views on extracurricular activities and employability. Active Learning in Higher Education, 16(2), 133-147.

Dardot, P and Laval, C (2013) The New Way of the World: On Neoliberal Society. London and New York: Verso.

Davis, A and Walsh, C (2017) Distinguishing Financialization from Neoliberalism. Theory, Culture, and Society, 34(5-6), 27-51

Deranty, J-P, (2008) Work and the Precarisation of Existence. European Journal of Social Theory, 11(4), 443-463.

Duménil, G and Lévy, D (2011) The Crisis of Neoliberalism. Harvard University Press: Camdrisge, MA.

Feher, M, (2009) Self Appreciation; or, the Aspirations of Human Capital. Public Culture, 21(2), 21-41.

Foucault, M, (1998) The History of Sexuality: The Will to Knowledge. London: Penguin Books.

Foucault, M, (2008) The Birth of Biopolitics: Lectures at the College de France 1978-1979. New York: Palgrave Macmillan.

French, S, Leyshon, A and Wainright, T, (2011) Financializing Space, Spacing Financialization. Progress in Human Geography, 798-819.

Gane, N, (2014) The Emergence of Neoliberalism: Thinking Through and Beyond Michel Foucault's Lectures on Biopolitics. Theory, Culture and Society, 31(4), 2-27.

Gillies, D, (2011) State education as high-yield investment: human capital theory in European policy discourse. Journal of Pedagogy, 2(2), 224-245.

Helleiner, E, (2010) A Bretton Woods Moment? The 2007-2008 Crisis and the Future of Global Finance. International Affairs, 86(3), 619-636.

Horton, J, (2017) Young people and debt: getting on with austerities. Area, 49(3), 280-287. 
Hunter, W, and Brown, D, (2000) World Bank Directives, Domestic Interests, and the Politics of Human Capital Investment in Latin America. Comparative Political Studies, 33(1), 113-143.

Joseph, M. (2014). Debt to society: Accounting for life under capitalism. Minneapolis: University of Minnesota Press.

Kotz, D, (2010) Financialization and Neoliberalism. in: Teeple, Gary \& McBride, Stephen (eds), Relations of Global Power: Neoliberal Order and Disorder. Toronto: Univeristy of Toronto Press, pp. 1-19.

Langley, P, (2007) The Uncertain Subjects of Anglo-American Financialization. Cultural Critique, 65, 66-91.

Lapavitsas, C (2009) Financialized Capitalism: Crisis and Financial Expropriation. Historical Materialism, 17(2), 114-148.

Lapavitsas, C, (2011) Theorizing Financialization. Work, Employment, and Society, 25(4), 611-626.

Lazonick, W and O'Sullivan, M, (2000) Maximizing shareholder value: a new ideology for corporate governance. Economy and Society, 29(1), 13-35.

Lazzarato, M, (2009) Neoliberalism in Action: Inequality, Insecurity and the Reconstitution of the Social. Theory, Culture and Society, 26(6), 109-133.

Lazzarato, M, (2012) The Making of Indebted Man. Los Angeles: Semiotext(e).

Lazzarato, M, (2015) Governing by Debt. Los Angeles: Semiotext(e).

Leyva, R, (2018) Towards a cognitive-sociological theory of subjectivity and habitus formation in neoliberal societies. European Journal of Social Theory, Epub ahead of print January 21, 2018. DOI: /10.1177/1368431017752909

Marazzi, C, (2011) The Violence of Financial Capital. Los Angeles: Semiotext(e).

Martin, R, (2002) The Financialization of Daily Life. Philadelphia: Temple University Press.

McClanahan, A, (2017) Dead Pledges: Debt, Crisis, and Twenty-First-Century Culture. Stanford, CA: Stanford University Press.

Moreau, M-P and Leathwood, C (2006) Graduates' employment and the discourse of employability: a critical analysis. Journal of Education and Work, 19(4), 305-324.

Mulcahy, N, (2017) Entrepreneurial Subjectivity and the Political Economy of Daily Life in the time of Finance. European Journal of Social Theory, 20(2), 216-235.

Nicoll, F, (2013) Finopower: Governing Intersections between Gambling and Finance. Communication and Critical/Cultural Studies, 10(4), 35-405.

Pitcher, B, (2016) Race, Debt and the Welfare State. New Formations, 87, 47-63

Qenani, E, MacDougall, N and Sexton, C, (2014) An empirical study of selfperceived employability: Improving the prospects for student employment success in an uncertain environment. Active Learning in Higher Education, 15(3), 199-213. 
Read, J, (2009) A genealogy of homo-economicus: Neoliberalism and the production of subjectivity. Foucault studies, 6, 25-36

Shildrick, T, MacDonald, R and Webster, C (2012). Poverty and Insecurity: Life in 'low-pay, No-pay' Britain. Bristol: Policy Press.

Standing, G. (2016[2011]). The Precariat: The New Dangerous Class. London: Bloomsbury

Stavrakakis, Y. (2013). Debt Society: Greece and the future of post-democracy. Radical Philosophy (181), 33-38.

Tomlinson, M, (2008) 'The degree is not enough': students' perceptions of the role of higher education credentials for graduate work and employability. British Journal of Sociology of Education, 29(1), 49-61.

Tymon, A, (2013) The student perspective on employability. Studies in Higher Education, 38(6), 841-856.

van Doorn, N. (2014). The Neoliberal Subject of Value: Measuring Human Capital in Information Economies. Cultural Politics, 10(3), 354-375.

Webster, J, (2016) Microworkers of the Gig Economy: separate and precarious. New Labor Forum, 25(3), 56-64. 